\title{
Influence of housing types and sex on the growth performance, haematological and serum biochemical parameter of broiler chickens
}

Egbeyale, L. T., Ndagimba J. R., Sogunle, O. M., Adeleye, O. O., Akinosi, O. K. and Ayo-Ajasa, O. Y.

Department of Animal Production and Health,

Federal University of Agriculture, P.M.B. 2240, Abeokuta, Nigeria.

Corresponding author:*egbeyalelt@funaab.edu.ng.Phone No: 08060743664

\section{Abstract}

This experiment was carried out to determine the effects of housing types and sex on growth and blood parameters of Arbor Acre broiler chickens. Three hundred (300) chicks, at two weeks of age were divided into two groups (male and female) each containing 150 birds. Each group was randomly sub-divided into two housing systems (deep litter and deep litter with run) consisting of three replicates with 25 birds per replicate and were fed ad libitum. Data collected were subjected to one-way analysis of variance in a $2 \times 2$ factorial arrangement. The housing type had no significant effect on the growth parameters measured. However, weight gain, feed intake and protein intake were influenced $(p<0.05)$ by sex. The effect of interaction between housing type and sex on the growth performances showed that male in the two housing systems had better $(p<0.05)$ performances than female. However, the female chickens in deep litter performed better $(p<0.05)$ than their female counterpart in deep litter with run. Haematological and biochemical parameters were not influenced by the main effect of housing type and sex. The interaction effect between the housing types and sex on the haematological and serum biochemical parameters had effect $(p<0.05)$ only on basophil and aspartate transferase. It was concluded that Arbor acre male broiler chickens can be raised on any of the housing types while female should be raised only on deep litter for better performance.

Keywords: Housing, sex, broiler, growth performance, haematology

\section{Introduction}

The livestock species are raised under different management system. The system of management defined the extent in which birds are exposed to sunlight or ultraviolent rays and it also describes the housing pattern. The challenge which continually faces broiler production is the provision of suitably designed house to provide optimum environment for maximum growth and production (Andrew and Mcpherson, 1993). The provision of appropriate good quality housing is still the most basic requirement for successful poultry production in spite of provision of specially formulated feeds, vitamin supplements, antibiotics, vaccines and other aids to intensive poultry production.
Studies have shown that intensive management system of poultry causes stress and also behavioural and physiological problems with negative effects on the health and productivity of birds (Hall, 2001; McLean et al., 2002; Bessei, 2005). Therefore, there is need to adopt technology to improve the wellbeing of birds in such a management system or to avoid the use of the system. It has been reported that provision of outdoor areas to birds has a favourable effect on their welfare as it allows them to express their natural behaviours such as moving, scratching, pecking, foraging and eating (Mahboub et al., 2004; Tuyttens et al., 2005). Bestman and Wagenaar (2003) and Nicol et al. (2003) reported that the use of free range by birds 


\section{Housing types and sex on the growth of broiler chickens}

not only boosts their immunity but helps to reduce stress experienced during rearing.

The recent challenge to find a suitable housing system for rearing birds to enhance growth performance and productivity in the poultry industry spurred the conduct of this experiment. This work was carried to determine the effect of housing types and sex on the growth performances, haematological and serum biochemical parameter of Arbor acre broiler chickens.

\section{Materials and methods Experiment Site:}

The experiment was carried out at the poultry unit of the Directorate of University Farm of the Federal University of Agriculture, Abeokuta, Ogun State, Nigeria. The area lies on latitude $7^{\circ} 10^{\prime} \mathrm{N}$ and longitude $3^{\circ} 2^{\prime} \mathrm{E}$, it received a mean precipitation of $1037 \mathrm{~mm}$ per annual an average temperature of $34.7^{\circ} \mathrm{C}$ and an average relative humidity of $82 \%$ throughout the year (Google Earth, 2014).

Experimental Design:

A total number of three hundred (300), two weeks old broiler chicks of Arbor Acres strain were purchased and sexed. The birds were divided into two groups (male and female) each containing 150 birds after the first two (2) weeks of brooding. Each group was randomly sub divided into two housing systems (deep litter and deep litter with run) a run is an extension outside the pen in which bird can move out to exercise its natural behaviour. Each group consisting of three replicates with 25 birds per replicate were given experimental diets at ad libitum and water. The study was carried out for 6 weeks (3-8weeks old). Vaccination schedule and medication for chicks were strictly adhered to. Broiler starter diet was formulated and given at starter phase $\left(15^{\text {th }}\right.$ 28th day) and broiler finisher diet at the finisher phase (29 - 56 days). The compositions of the diets are shown in the Table 1.

Table 1: Compositions (\%) of experimental diets

\begin{tabular}{lll}
\hline Ingredient & Starter & Finisher \\
\hline Maize & 41.50 & 47.50 \\
Soybean & 22.00 & 10.00 \\
Wheat offal & 13.00 & 20.00 \\
Groundnut & 16.00 & 15.00 \\
Fishmeal & 2.50 & 2.00 \\
Bone meal & 3.00 & 3.00 \\
Oyster shell & 1.00 & 1.00 \\
Vit/mineral premix & 0.25 & 0.25 \\
Salt & 0.25 & 0.25 \\
Methionine & 0.25 & 0.25 \\
Lysine & 0.25 & 0.25 \\
Total & 100.00 & 100.00 \\
Calculated Analysis & & \\
Crude protein & 22.23 & 20.18 \\
Energy (Mj/Kg) & 11.85 & 12.29 \\
\hline
\end{tabular}

\section{Data Collection:}

Data on growth performance (feed intake, body weight, feed conversion ratio and mortality) of each group were recorded weekly. Blood analyses were carried out on $8^{\text {th }}$ week of the experiment.

Collection of Blood Samples:

The blood was collected at $42^{\text {nd }}$ day of the experiment. Blood samples were collected from the wing vein from one bird per 


\section{Egbeyale, Ndagimba, Sogunle, Adeleye, Akinosi and Ayo-Ajasa}

replicate into tubes containing Ethylene Diamine Tetra Acetate (EDTA) to determined haematological parameters (packed cell volume, white blood cell, Haemoglobin, Red blood cell, Neutrophil, lymphocyte, Eosinophil, Basophil, monocytes and conjugated billirubin) while another $3 \mathrm{ml}$ were collected in to bottles without anti-coagulant to determine some serum biochemical parameters $\left(\mathrm{Ca}^{++}\right.$, $\mathrm{Na}^{++}$, Bicarbonate, Glucose, cholesterol, Total protein, Albumin, Globulin, Total billirubi, Conjugated billirubi, Serum glutamic pyruvic transminase, serum glutamic oxaloacetic transaminase, and Alkaline phosphate.

\section{Statistical Analysis}

The data were analyzed using the Randomized Complete Block Design (RCBD) of ANOVA according to SAS (2000). Significant $(\mathrm{P}<0.05)$ different means were separated using Duncan multiple ranged test of the software.

\section{Results and Discussion}

Table 2 shows the effects of housing type and sex on growth performance of broiler chickens. The result showed that housing type had no significant $(\mathrm{P}>0.05)$ effect on all the growth parameters measured. The similarity in the performances of broiler chickens in the two housing systems could be as a result of the quality of the systems and that they provided adequate comfort for the birds as it can also be seen that the mortality is within normal range. Bell and Weaver (2001) found that housing conditions of poultry birds play very important role and poultry parent stock should be provided the conditions that ensure optimum performance of the birds. Many researchers had found out that improvement in the housing system results in improved welfare health of the birds (Lewis and Morris, 2006; Ahlers et al., 2009).

Table 2: Main effect of housing types and sex on growth performance of broiler chickens

\begin{tabular}{|c|c|c|c|c|}
\hline \multirow[b]{2}{*}{ Parameters } & \multicolumn{2}{|c|}{ Housing type } & \multicolumn{2}{|c|}{ Sex } \\
\hline & $\begin{array}{l}\text { Deep litter } \\
\text { with run }\end{array}$ & Deep litter & Female & Male \\
\hline Initial weight $(\mathrm{g})$ & $334.67 \pm 9.09$ & $342.04 \pm 14.83$ & $333.37 \pm 11.14$ & $343.33 \pm 12.30$ \\
\hline Final weight $(\mathrm{g})$ & $2050.33 \pm 200.51$ & $\begin{array}{l}2140.60 \pm 2050.3 \\
3\end{array}$ & $1966.21 \pm 109.53^{\mathrm{b}}$ & $2224.73 \pm 74.41^{\mathrm{a}}$ \\
\hline Weight gain $(\mathrm{g})$ & $1715.67 \pm 203.24$ & $1798.57 \pm 103.03$ & $1632.84 \pm 113.86^{\mathrm{b}}$ & $1881.39 \pm 77.54^{\mathrm{a}}$ \\
\hline Weight gain per day $(\mathrm{g})$ & $40.85 \pm 4.84$ & $42.82 \pm 2.43$ & $38.88 \pm 2.71^{\mathrm{b}}$ & $44.80 \pm 1.85^{\mathrm{a}}$ \\
\hline Total feed intake $(\mathrm{kg})$ & $4.77 \pm 0.27$ & $4.91 \pm 0.49$ & $4.54 \pm 0.70^{\mathrm{b}}$ & $5.14 \pm 0.33^{\mathrm{a}}$ \\
\hline Feed intake per day $(\mathrm{g})$ & $113.69 \pm 6.33$ & $116.85 \pm 11.75$ & $108.17 \pm 1.61^{\mathrm{b}}$ & $122.37 \pm 7.78^{\mathrm{a}}$ \\
\hline FCR & $2.80 \pm 0.19$ & $2.73 \pm 0.16$ & $2.79 \pm 0.19$ & $2.73 \pm 0.16$ \\
\hline Protein intake (g/day) & $23.87 \pm 1.33$ & $24.54 \pm 2.47$ & $22.72 \pm 0.33^{b}$ & $25.70 \pm 1.63^{\mathrm{a}}$ \\
\hline Protein efficiency & $1.71 \pm 0.11$ & $1.75 \pm 0.10$ & $1.71 \pm 0.11$ & $1.75 \pm 0.10$ \\
\hline Mortality $(\%)$ & $4.67 \pm 4.68$ & $1.33 \pm 2.07$ & $4.67 \pm 4.68$ & $1.33 \pm 2.07$ \\
\hline
\end{tabular}

However, the effect of sex on growth performance was reflected $(p<0.05)$ in final weight gain, weight gain per day, feed intake and protein intake. The male birds were significantly $(\mathrm{p}<0.05)$ heavier $(2224.73 \mathrm{~g} /$ day) than their female counterpart which recorded $1966.21 \mathrm{~g} /$ day at the end of the experiment. The average total weight gain of male birds was
$1881.39 \mathrm{~g}$ while that of the female was $1632.84 \mathrm{~g}$, the weight gain of the birds per day were 44.80 and $38.88 \mathrm{~g} /$ day for the male and female, respectively. The feed intake per day of the male birds increased significantly $(p<0.05)$ than the females. The feed intake pattern of male and female broiler chicken obtained agreed with the report of Laseinde and Oluyemi (1996). 


\section{Housing types and sex on the growth of broiler chickens}

The authors also reported that male birds grow faster and weigh heavier than the females under various rearing conditions. This could be attributed to the higher activity of the males than the females. Fischer (1985) reported that male birds are behaviourally more active than the females; hence consumed more feeds and gain weight faster than the females. The result of the interaction between housing type and sex on growth performances of broiler chickens (3-8weeks) is shown on Table 3. The result showed that interaction between housing types and sex has significant $(p<0.05)$ effect on all the parameters except mortality. Interaction across the treatments showed that male in the housing system had better performances than female. However, the female chickens in deep litter performed better $(p<0.05)$ than their female counterpart in deep litter with run The male birds on deep litter and deep litter with run recorded highest final weight $(\mathrm{p}<0.05)$ of 2231.90 and $2217.56 \mathrm{~g}$ which were heavier than the female on deep litter and deep litter with run 2049.31 and $1883.11 \mathrm{~g}$, respectively. It also reflected that weight gain per day of female bird reared on deep litter with run recorded the least value of $36.85 \mathrm{~g}$. The protein intake and protein efficiency ratio were also influenced $(p<0.05)$ by the effect of interaction. Female birds managed on deep litter had increased values of final weight and weight compared to their counterpart in deep litter with run. This could be due to the energy dispersed by the latter as they move freely on run, these finding agreed with the observation of Castellini et al. (2008) who reported that outdoor activities reduces growth rate and influenced mortality rate than birds managed on deep litter. However, mortality was not influenced in the present study. The insignificant value mortality in the present study negated the report of Santos et al. (2012) that housing type had significant effect on mortality. The variation could be due to the differences in the housing type used in these studies.

Table 3: Effect of interaction between the housing systems and sex on growth performance of broiler chickens (3-8 weeks)

\begin{tabular}{llllll}
\hline & \multicolumn{2}{c}{ Female } & & \multicolumn{2}{c}{ Male } \\
\cline { 2 - 3 } \cline { 5 - 6 } Parameter & Deep litter & $\begin{array}{l}\text { Deep litter } \\
\text { with run }\end{array}$ & & Deep litter & $\begin{array}{l}\text { Deep litter } \\
\text { with run }\end{array}$ \\
\hline Initial weight(g) & $331.41 \pm 13.9^{\mathrm{b}}$ & $335.33 \pm 10.26^{\mathrm{ab}}$ & & $352.67 \pm 4.16^{\mathrm{a}}$ & $334.00 \pm 10.00^{\mathrm{ab}}$ \\
Final weight $(\mathrm{g})$ & $2049.31 \pm 21.08^{\mathrm{b}}$ & $1883.11 \pm 93.99^{\mathrm{c}}$ & & $2231.90 \pm 76.83^{\mathrm{a}}$ & $2217.56 \pm 88.23^{\mathrm{a}}$ \\
Weight gain(g) & $1717.90 \pm 30.35^{\mathrm{b}}$ & $1547.77 \pm 98.91^{\mathrm{c}}$ & & $1879.23 \pm 78.09^{\mathrm{a}}$ & $1883.56 \pm 94.44^{\mathrm{a}}$ \\
Weight per day(g) & $40.90 \pm 0.72^{\mathrm{b}}$ & $36.85 \pm 2.35^{\mathrm{c}}$ & & $44.74 \pm 1.86^{\mathrm{a}}$ & $44.85 \pm 2.25^{\mathrm{a}}$ \\
Feed intake(kg) & $4.54 \pm 0.03^{\mathrm{b}}$ & $4.55 \pm 0.10^{\mathrm{b}}$ & & $5.28 \pm 0.44^{\mathrm{a}}$ & $4.10 \pm 0.12^{\mathrm{a}}$ \\
Feed per day(g) & $107.99 \pm 0.61^{\mathrm{b}}$ & $108.34 \pm 2.45^{\mathrm{b}}$ & & $125.71 \pm 10.46^{\mathrm{a}}$ & $119.03 \pm 2.91^{\mathrm{a}}$ \\
Feed conversion ratio & $2.64 \pm 0.06^{\mathrm{b}}$ & $2.95 \pm 0.13^{\mathrm{a}}$ & & $2.81 \pm 0.19^{\mathrm{ab}}$ & $2.66 \pm 0.09^{\mathrm{b}}$ \\
Protein intake (g/day) & $22.68 \pm 0.12^{\mathrm{b}}$ & $22.75 \pm 0.51^{\mathrm{b}}$ & & $26.40 \pm 2.19^{\mathrm{a}}$ & $24.10 \pm 0.61^{\mathrm{a}}$ \\
Protein efficient ratio & $1.80 \pm 0.04^{\mathrm{a}}$ & $1.62 \pm 0.7^{\mathrm{b}}$ & & $1.70 \pm 0.12^{\mathrm{ab}}$ & $1.79 \pm 0.60^{\mathrm{a}}$ \\
Mortality (\%) & $2.67 \pm 2.31$ & $6.67 \pm 6.11$ & & $0.00 \pm 0.00$ & $2.67 \pm 2.31$ \\
\hline abc Mean in the same row with different superscripts are significant $(\mathbf{p}<0.05)$. & & &
\end{tabular}

The effect of housing type and sex on haematological and serum biochemical parameters is represented in Table 4 . The result showed that all the parameters measured were not influenced $(p>0.05)$ by housing type or sex. The PCV values ranged from 33.25 to $33.75 \%$ in the two housing types. Birds on deep litter recorded 2.50 $\times 10^{12} / \mathrm{L}$ and $11.70 \times 10^{9} / \mathrm{L}$ for Red blood cell and White blood cell while their counterpart 


\section{Egbeyale, Ndagimba, Sogunle, Adeleye, Akinosi and Ayo-Ajasa}

on deep litter with run recorded 2.68 x 1012/Land $11.95 \times 109 / \mathrm{L}$, respectively.

Table 4: The main effect of housing type and sex on of haematological and serum biochemical parameters

\begin{tabular}{|c|c|c|c|c|}
\hline \multirow[b]{2}{*}{ Parameters } & \multicolumn{2}{|c|}{ Housing type } & \multicolumn{2}{|c|}{ Sex } \\
\hline & Deep litter & $\begin{array}{l}\text { Deep litter } \\
\text { with run }\end{array}$ & Female & Male \\
\hline PCV (\%) & $33.25 \pm 4.11$ & $33.75 \pm 5.25$ & $32.75 \pm 3.40$ & $34.25 \pm 6.68$ \\
\hline Haemoglobin (g/dl) & $10.78 \pm 1.38$ & $10.88 \pm 1.45$ & $10.73 \pm 0.93$ & $10.93 \pm 1.77$ \\
\hline $\mathrm{RBC}\left(\mathrm{X} 10^{12} / \mathrm{L}\right)$ & $2.50 \pm 0.51$ & $2.68 \pm 0.43$ & $2.55 \pm 0.26$ & $2.63 \pm 0.62$ \\
\hline $\mathrm{WBC}\left(\mathrm{X} 10^{9} / \mathrm{L}\right)$ & $11.70 \pm 1,37$ & $11.95 \pm 1,98$ & $11.40 \pm 1.13$ & $12.25 \pm 2.02$ \\
\hline Heterophil (\%) & $35.50 \pm 5.45$ & $37.00 \pm 4.69$ & $34.75 \pm 6.40$ & $37.75 \pm 2.50$ \\
\hline Lymphocyte (\%) & $63.50 \pm 4.93$ & $62.75 \pm 4.35$ & $64.25 \pm 5.62$ & $62.00 \pm 2.94$ \\
\hline Eosinophil (\%) & $0.25 \pm 0.00$ & $0.50 \pm 0.00$ & $0.00 \pm 0.00$ & $0.25 \pm 0.50$ \\
\hline Basophil (\%) & $0.50 \pm 0.00$ & $0.58 \pm 0.00$ & $0.50 \pm 0.58$ & $0.00 \pm 0.00$ \\
\hline Monocyte (\%) & $0.25 \pm 0.50$ & $0.25 \pm 0.50$ & $0.50 \pm 0.58$ & $0.00 \pm 0.00$ \\
\hline Total protein $(\mathrm{g} / \mathrm{dl})$ & $7.20 \pm 0.41$ & $6.83 \pm 0.83$ & $7.10 \pm 0.68$ & $6.93 \pm 0.68$ \\
\hline Albumin (g/dl) & $3.40 \pm 0.37$ & $3.75 \pm 0.64$ & $3.83 \pm 0.59$ & $3.33 \pm 0.33$ \\
\hline $\begin{array}{l}\text { Aspartate transferase } \\
\text { (iu/L) }\end{array}$ & $69.00 \pm 7.44$ & $72.5 \pm 13.72$ & $75.50 \pm 12.12$ & $66.00 \pm 6.68$ \\
\hline $\begin{array}{l}\text { Alanine transferase } \\
\text { (iu/L) }\end{array}$ & $27.75 \pm 2.99$ & $28.25 \pm 6.13$ & $25.50 \pm 3.87$ & $30.50 \pm 3.87$ \\
\hline Glucose $(\mathrm{Mg} / \mathrm{dl})$ & $118.5 \pm 16.44$ & $114.25 \pm 15.63$ & $109.50 \pm 17.84$ & $123.25 \pm 9.07$ \\
\hline Cholesterol (Mg/dl) & $70.25 \pm 20.25$ & $76.00 \pm 16.37$ & $77.00 \pm 19.88$ & $69.25 \pm 16.26$ \\
\hline Bicarbonate & $15.40 \pm 3.38$ & $14.73 \pm 2.57$ & $15.65 \pm 2.13$ & $14.48 \pm 3.59$ \\
\hline Calcium(Mg/dl) & $10.75 \pm 1.57$ & $10.18 \pm 0.57$ & $10.10 \pm 1.14$ & $10.83 \pm 1.17$ \\
\hline Sodium & $143.5 \pm 11.12$ & $143.75 \pm 3.77$ & $143.00 \pm 7.78$ & $144.25 \pm 8.66$ \\
\hline Total bilirubin & $0.15 \pm 0.04$ & $0.12 \pm 0.02$ & $0.14 \pm 0.20$ & $0.13 \pm 0.50$ \\
\hline Conjugated billirubin & $0.12 \pm 0.40$ & $0.07 \pm 0.02$ & $0.88 \pm 0.04$ & $0.09 \pm 0.04$ \\
\hline Globulin & $3.80 \pm 0.74$ & $3.08 \pm 0.83$ & $3.28 \pm 1.13$ & $3.60 \pm 0.50$ \\
\hline $\begin{array}{l}\text { Alanine transferase } \\
\text { (ALT) }\end{array}$ & $30.75 \pm 2.5$ & $32.75 \pm 4.90$ & $33.50 \pm 4.51$ & $30.00 \pm 2.16$ \\
\hline
\end{tabular}

Table 5 showed that the effect of interaction between housing type and sex on the haematological and serum biochemical parameters of broiler chicken had no significant $(p>0.05)$ effect in all the parameters measured except basophil and Aspartate transferase. It was shown that only the female birds on deep litter had basophil. The result of aspartate transferase (AST) showed that female on deep litter with run had the least value of 61.50 while the highest value (83.50) was recorded from male on deep litter with run. The effect of housing type on haematology variables can be best known through understanding of haematological concept, however all the haematology parameters of housing type fall within the normal range for chickens. Haematology is a scientific study of the natural functions and diseases of the blood on the other hand, those factors in the blood are usually determined in order to assess the degree of health of the animal. The blood parameters obtained in this study shows that the birds' health status was not adversely affected by the housing systems. The values of PCV and RBC also showed that the birds were not anaemic since the two indices are 


\section{Housing types and sex on the growth of broiler chickens}

good indicators of the blood volume and oxygen carrying capacity. The immune response of the birds was not negatively affected by the housing system as observed in the values of the WBC which were normal. The non-significant effect of housing in the values of blood parameters was in line with the founding of Alabi et al. (2015) who reported that the haematological values of the laying hens were not influenced by the housing. The similarities in the haematological parameters also agreed with the findings of Olaniyi et al. (2012) in cockerel chickens reared on deep litter and free range systems. Even though, the effect of sex was insignificant on both haematological and serum biochemical indices, this contradicted the result of Sharmin and Myenuddin (2004). The difference in the observation may be attributed to the level of significance because the authors subjected their data to $99 \%(\mathrm{p}<0.01)$ while in the present study it was at $95 \%$. It could also be that the birds were of the same age, reared for short period of eight weeks and managed under the same environment (season and feed). The insignificant effect of housing type on blood parameters could be due to similar conditions of husbandry system under which the bird were kept. The result was in agreement with the report of Addass et al. (2012) who worked on management system on some haematological parameters of intensively and semi-intensively kept chickens. The study showed that the housing types did not impose significant effect on growth performance and blood (haematological and serum biochemical) parameters of broiler chickens.

Table 5: Effect of interaction between housing type and sex on the haematological and serum biochemical parameter of broiler chickens

\begin{tabular}{|c|c|c|c|c|}
\hline \multirow[b]{2}{*}{ Para meter } & \multicolumn{2}{|c|}{ Deep litter } & \multicolumn{2}{|c|}{ Deep litter with run } \\
\hline & Female & Male & Female & Male \\
\hline PCV (\%) & $33.50 \pm 0.71$ & $33.00 \pm 7.07$ & $35.50 \pm 6.36$ & $32.00 \pm 5.66$ \\
\hline $\mathrm{HB}(\mathrm{g} / \mathrm{dl})$ & $11.00 \pm 0.28$ & $10.55 \pm 2.33$ & $11.30 \pm 1.83$ & $10.45 \pm 1.49$ \\
\hline $\mathrm{RBC}\left(\mathrm{X} 10^{12} / \mathrm{L}\right)$ & $2.60 \pm 0.14$ & $2.40 \pm 0.83$ & $2.85 \pm 0.49$ & $2.50 \pm 0.42$ \\
\hline WBC $\left(X 10^{9} / \mathrm{L}\right)$ & $11.55 \pm 0.35$ & $11.85 \pm 2.33$ & $12.65 \pm 2.47$ & $11.25 \pm 1.91$ \\
\hline Heterophil (\%) & $32.00 \pm 5.65$ & $39.00 \pm 2.83$ & $36.50 \pm 2.12$ & $37.50 \pm 7.78$ \\
\hline Lymphocyte (\%) & $66.50 \pm 4.95$ & $60.5 \pm 3.54$ & $63.50 \pm 2.12$ & $62.00 \pm 7.07$ \\
\hline Eosinophils (\%) & $0.00 \pm 0.00$ & $0.50 \pm 0.71$ & $0.00 \pm 0.00$ & $0.00 \pm 0.00$ \\
\hline Basophil (\%) & $1.00 \pm 0.00^{\mathrm{a}}$ & $0.00 \pm 0.00^{\mathrm{b}}$ & $0.00 \pm 0.00^{\mathrm{b}}$ & $0.00 \pm 0.00^{\mathrm{b}}$ \\
\hline Monocyte $(\%))$ & $0.50 \pm 0.70$ & $0.00 \pm 0.00$ & $0.00 \pm 0.00$ & $0.50 \pm 0.71$ \\
\hline Total protein $(\mathrm{g} / \mathrm{dl})$ & $7.15 \pm 0.49$ & $7.25 \pm 0.50$ & $6.60 \pm 0.85$ & $7.05 \pm 1.11$ \\
\hline Albumin (g/dl) & $3.45 \pm 0.64$ & $3.35 \pm 0.70$ & $33.00 \pm 4.24$ & $4.20 \pm 0.28$ \\
\hline Aspartate transferase $(\mathrm{iu} / \mathrm{L})$ & $67.50 \pm 12.02^{\mathrm{ab}}$ & $70.50 \pm 3.54^{\mathrm{ab}}$ & $61.50 \pm 6.36^{\mathrm{b}}$ & $83.50 \pm 6.36^{\mathrm{a}}$ \\
\hline Alanine transferase $(\mathrm{iu} / \mathrm{L})$ & $27.50 \pm 4.49$ & $28.00 \pm 1.41$ & $33.00 \pm 4.24$ & $23.50 \pm 2.12)$ \\
\hline glucose $(\mathrm{Mg} / \mathrm{dl})$ & $118.00 \pm 25.46$ & $199.00 \pm 12.75$ & $127.50 \pm 3.53$ & $101.00 \pm 4.24$ \\
\hline cholesterol (Mg/dl) & $79.00 \pm 29.70$ & $61.50 \pm 6.36$ & $77.00 \pm 22.63$ & $75.00 \pm 16.97$ \\
\hline Bicarbonate $(\mathrm{Mmol} / \mathrm{l})$ & $146.00 \pm 2.40$ & $16.20 \pm 5.09$ & $12.75 \pm 0.92$ & $16.70 \pm 1.84$ \\
\hline Calcium $(\mathrm{Mg} / \mathrm{dl})$ & $10.05 \pm 1.91$ & $11.45 \pm 1.34$ & $10.20 \pm 0.85$ & $10.15 \pm 0.50$ \\
\hline Sodium & $145 \pm 12.72$ & $142.00 \pm 14.14$ & $146.50 \pm 2.12$ & $141.00 \pm 2.83$ \\
\hline Total bilirubin & $0.15 \pm 0.02$ & $0.15 \pm 0.07$ & $0.11 \pm 0.01$ & $0.13 \pm 0.04$ \\
\hline Conjugated bilirubin & $0.11 \pm 0.05$ & $0.11 \pm 0.60$ & $0.08 \pm 0.01$ & $0.07 \pm 0.03$ \\
\hline Globulin & $3.70 \pm 1.13$ & $3.90 \pm 0.57$ & $3.30 \pm 0.28$ & $2.85 \pm 1.34$ \\
\hline Alanine transferase (ALT) & $31.00 \pm 4.24$ & $30.50 \pm 0.71$ & $29.5 \pm 3.54$ & $36.00 \pm 4.24$ \\
\hline
\end{tabular}




\section{Conclusion}

The male broiler chicken of arbor acre strain can be raised on any of the two housing type without any difference in their performance while their female counterpart should be raised on deep litter for optimum performance.

\section{Acknowledgements}

The authors acknowledged the contribution of Miss J. A. Adegbite, the laboratory technologist of the Department of Animal Production and Health, Federal University of Agriculture, Abeokuta, Ogun State, Nigeria.

\section{References}

Addass, P. A., David, D. L., Edward, A., Zira, K. E. and Midau, A. 2012. Effect of Age, Sex and Management System on Some Haematological Parameters of Intensively and Semi-Intensively Kept Chicken in Mubi, Adamawa State, Nigeria. Iranian Journal of Applied Animal Science 3(2): 277-282.

Ahlers, C., Alders, R. G., Aagnol, B., Cambaza, A. B., Harun, M. and Young, M. 2009. Improving village chicken production: a manual or field workers and trainers. vol. 1, pp. 5567. Canberra, ACIAR, Australia.

Alabi, O. M., Aderemi, F. A. and Adeniji, O. B., 2015. Effect of alternative housing systems on blood profile of egg-type chickens in humid tropic. American Journal of Experimental Agriculture 7(4): 197-204.

Andrew, L.O. and Mcpherson, B. N. 1993. Comparison of different types of materials for broilers litter. Poultry Science, 42:249-254.

Bell, D.D. and Weaver, W. D. 2001. Commercial chicken meat and egg production, 5th edition. Kluwer, Los Angeles, California, USA.
Bessei, W. 2005. Welfare of meat producing poultry - an overview. Animal science papers and reports, 23, Suppl. 1: 205-216.

Bestman, M. W. P. and Wagenaar, J. P. 2003. Farm level factors associated with feather pecking in organic laying hens. Livestock Production Science, 80: 133-140.

Castellini, C., Berri, C., Le Bihan-Duval, E. and Martino, G. 2008. Qualitative attributes and consumer perception of organic and free-range poultry meat. Worlds Poultry Science Journal, 64:500-512.

Fischer, G. J. 1985. The behaviour of chicken. In: Bailliere Tindal. Pp. 454-487.

Google Earth, 2014. Google location map; Google earth imagery.

Hall, A. L. 2001. The effect of stocking density on the welfare and behaviour of broiler chickens reared commercially. Animal Welfare, 10, 1: 23-40.

Laseinde, E. A. and Oluyemi, J. A. 1996. Sexual Dimorphism in the Growth Pattern of broilers under different dietary and housing conditions. Nigerian Journal of Animal Production, 24: 1-6.

Lewis, P. and Morris, T. 2006. Poultry lighting: the theory and practice. Nottingham University Press, Nottingham, UK.

Mahboub, H. D. H., Müller, J. and Borell, E. 2004. Outdoor use, tonic immobility, heterophil/lym- phocyte ratio and feather condition in freerange laying hens of different genotype. British Poultry Science, 45(6): 738-744.

Mclean, J. A., Savory, C. J. and Sparks, N. H. C. 2002. Welfare of male and female broiler chickens in relation to 
stocking density, as indicated by performance, health and behaviour. Animal Welfare, 11: 55-73.

Nicol, C. J., Pötzsch, C., Lewis, K. and Greek, L. E. 2003. Matched concurrent case-control study of risk factors for feather pecking in hens on free-range commercial farms in the UK. Brit. Poultry Science, 44: 515-523.

Olaniyi, O. A., Oyenaiya, O. A., Sogunle, O. M., Akinola, O. S., Adeyemi, O. A. and Ladokun, O. A. 2012. Free range and deep litter housing systems: Effect on performance and blood profile of two strains of cockerel chickens. Tropical and Subtropical Agroecosystems, 15: 511 -523 .
Santos, F. B. O., Santos Jr., A. A., OviedoRondon, E. O. and Ferket, P. R. 2012. Influence of housing system on growth performance and intestinal health of Salmonella challenged broiler chickens. Current Research in Poultry Science, 2(1): 110.

Sharmin, M. L. and Myenuddin, M. 2004. Haematological values of the indigenous chickens. Bangladesh Journal of. Veterinary Medicine, 2 (2): 163-164.

Tuyttens, F., Heyndrickx, M., De Boeck, M., Moreels, A., Van Nuffel, A., VanPoucke, E., Van Coillie, E., Van Dongen, S., Lens, L. 2005. Comparison of broiler chicken health and welfare in organic versus traditional production systems. Animal Science Paper and.Reports, 23, Suppl., 1:217-222.

Received: $7^{\text {th }}$ February, 2017 Accepted: $21^{\text {st }}$ June, 2017 